\title{
Sinergitas Self-Regulated dan Kemandirian Belajar Terhadap Prestasi Belajar Bahasa Arab
}

\author{
Anifatus Sa'idah, M.Pd \\ IAIN Kudus, Jawa Tengah, Indonesia \\ anifatussaidah@gmail.com
}

\section{Abstract}

This study aims to reveal the synergy of the relationship between selfregulated learning and learning independence of Arabic learning achievement among students of Madrasah Aliyah Mu'allimat Muhammadiyah Yogyakarta 2015/2016 academic year.

This research is a regression analysis research with quantitative approach. The population in this study were students of Class $X$ Multilingual MA Mu'allimat Muhammadiyah Yogyakarta 2015/2016 academic year. The sampling technique is a purposive sampling technique that is 120 students in multilingual classes which are divided into 3 classes, namely classes $C, D$ and $E$ who settled in the dormitory.

The results of this study state that there is a significant synergy between self-regulated learning and learning independence of the Arabic learning achievement of MA Mu'allimat Muhammadiyah Yogyakarta students. Selfregulated learning (X1) contributed $28.2 \%$, the contribution of learning independence $(\mathrm{X} 2)$ was $18.5 \%$ and the contribution of both together was $11.9 \%$ while the remaining $88.1 \%$ was influenced by other variables outside Research such as motivation, discipline, learning environment, methods, teaching style of teachers, supporting facilities and learning facilities.

Keywords: self-regulated learning, learning independence and learning achievement.

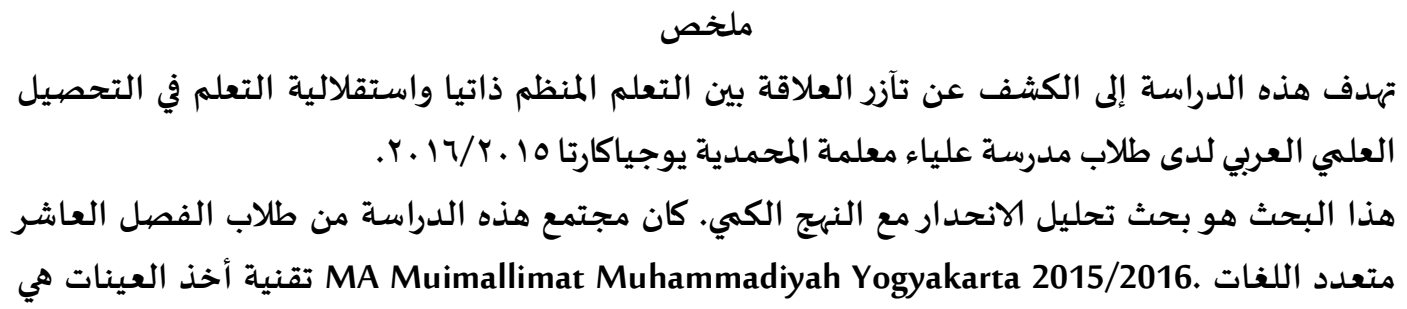




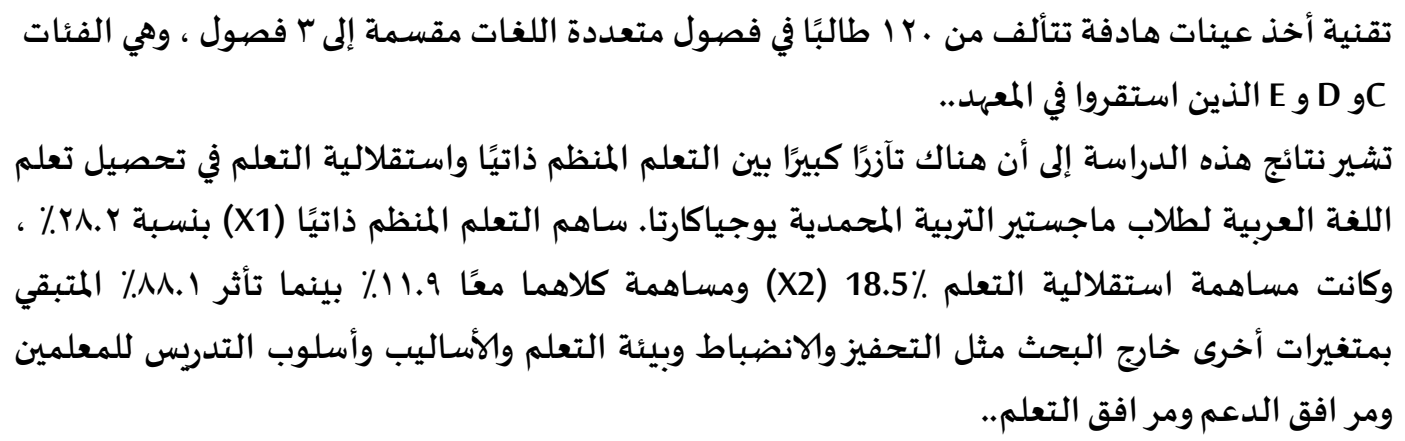

Penelitian ini bertujuan untuk mengungkapkan sinergitas hubungan antara self-regulated learning dan kemandirian belajar terhadap prestasi belajar bahasa Arab pada siswi Madrasah Aliyah Mu'allimat Muhammadiyah Yogyakarta tahun ajaran 2015/2016.

Penelitian ini merupakan penelitian analisis regresi dengan pendekatan kuantitatif. Adapun populasi dalam penelitian ini adalah siswi kelas $X$ Multilingual MA Mu'allimat Muhammadiyah Yogyakarta tahun ajaran 2015/2016. Teknik pengambilan sampel adalah teknik purposive sampling yaitu 120 siswi pada kelas multilingual yang terbagi dalam 3 kelas yaitu kelas $C$, $D$ dan $E$ yang menetap di asrama.

Hasil penelitian ini menyatakan bahwa ada sinergitas yang signifikan antara self-regulated learning dan kemandirian belajar terhadap prestasi belajar bahasa Arab siswi MA Mu'allimat Muhammadiyah Yogyakarta. selfregulated learning $\left(X_{1}\right)$ memberikan kontribusi sebesar $28,2 \%$, kontribusi kemandirian belajar $\left(\mathrm{X}_{2}\right)$ sebesar $18,5 \%$ dan kontribusi keduanya secara bersama-sama sebesar 11,9\% sedangkan sisanya 88,1\% dipengaruhi oleh variabel lain di luar penelitian seperti motivasi, kediplinan, lingkungan belajar, metode, gaya mengajar guru, sarana-prasarana dan fasilitas pembelajaran yang turut mendukung.

Kata Kunci : self-regulated learning, kemandirian belajar dan prestasi belajar.

\section{PENDAHULUAN}

Mempelajari bahasa Asing termasuk bahasa Arab sebagai bahasa kedua (B2) tidaklah sama dengan mempelajari bahasa pertama (B1), yang tampak jelas adalah orang yang mempelajari bahasa kedua (B2) pernah memiliki pengalaman bahasa sebelumnya, karena itu pengalaman bahasa pada tiap-tiap orang sangat berbeda-beda. Seseorang yang hanya menggunakan satu bahasa sejak kecil, akan memiliki kebiasaan berfikir yang terikat oleh kebiasaan menggunakan bahasa yang diketahuinya. (A.S Broto, $1980: 66$ )

Begitu pula dengan bahasa Arab, untuk mempelajari dan memahami bahasa Arab bukanlah hal yang mudah. Oleh karena itu, dibutuhkan upaya 
siswa untuk mempelajari dan memahami bahasa Arab secara intensif sehingga pencapaian prestasi siswa bisa optimal. Adapun upaya belajar yang dibutuhkan oleh siswa dalam memepelajari dan memahami bahasa Arab itu salah satunya adalah dengan belajar berdasarkan self-regulated learning.

Self-regulated learning menunjuk kepada belajar yang sebagian besar terjadi dari pikiran, strategi, dan perilaku yang dihasilkan pembelajar sendiri yang ditujukan kepada pencapaian tujuan. Siswa yang memiliki selfregulated learning akan secara aktif dalam melakukan aktifitas belajarnya (Schunk \& Zimmerman, 1998 : viii). Siswa dikembangkan menjadi seseorang yang memiliki pengetahuan tentang strategi belajar yang efektif, yang sesuai dengan gaya belajarnya, dan tahu bagaimana serta kapan menggunakan pengetahuan itu dalam situasi pembelajaran yang berbeda (Suyono \& Hariyanto, 2011 : 111). Penggunaan self-regulated learning sebagai suatu bentuk upaya siswa dalam memotivasi diri untuk dapat mencapai hasil yang optimal dalam belajar. Jadi dapat dikatakan bahwa semakin baik selfregulated learning, maka akan semakin baik hasil prestasi yang dapat dicapai. Sebaliknya, jika siswa memiliki self-regulated learning yang rendah, maka kurang dapat melakukan perencanaan, pemantauan, evaluasi pembelajaran dengan baik, kurang mampu melakukan pengelolaan potensi dan sumber daya yang baik dan sebagainya, sehingga hasil dari belajarnya tidak optimal, sesuai dengan potensi diri yang dimilikinya (Suyono \& Hariyanto, 2011 : 112).

Masalah lain selain self-regulated learning yang ikut mempengaruhi tingkat prestasi belajar siswa adalah kemandirian belajar. Beberapa siswa malas belajar bahasa Arab dan hanya akan belajar ketika ada ujian. Hal tersebut mengindikasikan bahwa kemandirian belajar siswa masih rendah. Umar Tirtarahardja dan La Sulo mengungkapkan dalam bukunya yang berjudul "Pengantar Pendidikan" bahwa kemandirian dalam belajar adalah aktivitas belajar yang berlangsungnya lebih didorong oleh kemauan sendiri, pilihan sendiri dan tanggung jawab sendiri. Dengan kemandirian belajar siswa akan belajar menguasai materi dengan usaha sendiri tanpa adanya guru atau disuruh orangtua sehingga siswa akan cenderung positif untuk mencapai tujuan dengan menguasai materi dan memperoleh prestasi yang memuaskan (Umar \& La Sulo, 2005 : 50).

Jadi, jika siswa merasa bahwa suatu pelajaran atau pembahasan pelajaran tidak dimengerti, maka siswa akan lebih aktif untuk dapat mempelajarinya. Seperti membuat perencanaan apa yang akan dipelajari lagi, melakukan pemantauan terhadap hasil belajarnya, mengevaluasi hasil belajar yang diperoleh, mengulang, mengorganisasi belajarnya, berusaha untuk mencapai prestasi yang optimal, dan termasuk mencari bantuan pada teman, guru atau orang yang dianggap lebih mengerti.

Kemandirian belajar juga merupakan belajar di masa depan. Di satu sisi tantangan kehidupan semakin keras, dan masalah yang menghadang kehidupan manusia semakin banyak, di sisi lain biaya pendidikan dalam sistem tradisional semakin mahal. Satu segi yang menguntungkan pada masa 
ini adalah semakin tersedianya sumber-sumber belajar yang dapat dipelajari sendiri, tanpa perlu banyak bantuan dari orang lain. sumber-sumber ini terutama berupa pustaka, baik pustaka konvensional maupun elektronik (Haris, $2008: 2$ ).

Alasan penulis memilih Madrasah Aliyah Mu'allimat Muhammadiyah Yogyakarta sebagai tempat penelitian adalah berdasarkan pengamatan penulis terhadap sekolah tersebut, penulis sempat mengamati perilaku siswa yang tertib dan kondusif. Sementara, hal lain yang membuat peneliti tertarik untuk melakukan penelitian di madrasah tersebut adalah adanya fasilitas asrama yang turut mendukung dalam proses pembelajaran di sekolah. Asrama tersebut diperuntukkan kepada siswi kelas X Multilingual, setiap asrama memiliki kegiatan yang telah terjadwal dan dibina oleh musyrif dan musyrifah masing-masing.

\section{Metode Penelitian}

Penelitian ini menggunakan pendekatan kuantitatif, yaitu pendekatan penelitian yang bekerja dengan angka, datanya terwujud bilangan yang dianalisis dengan menggunakan statistik untuk menjawab hipotesis penelitian (Margono, 2004 : 35). Penelitian ini termasuk dalam penelitian regresi. Adapun identifikasi variabel penelitian ini adalah: a) Variabel bebas (independent) dalam penelitian ini adalah self-regulated learning dan kemandirian belajar dan b) Variabel terikat (dependent) dalam penelitian ini adalah prestasi belajar.

Metode pengumpulan data meliputi Observasi, Angket (Kuesioner), Dokumentasi.

1. Kisi-kisi umum

\begin{tabular}{|l|l|l|l|l|}
\hline No & Variabel Penilaian & Sumber Data & Metode & Instrumen \\
\hline & $\begin{array}{l}\text { Self-regulated } \\
\text { Learning }\end{array}$ & Siswi & Angket & Angket \\
\hline 2 & $\begin{array}{l}\text { Kemandirian } \\
\text { Belajar }\end{array}$ & Siswi & Angket & Angket \\
\hline 3 & Prestasi Belajar & Nilai UAS & Dokumentasi & Daftar Nilai \\
\hline
\end{tabular}

2. Kisi-kisi khusus (angket untuk siswi)

1) Skala Self-regulated Learning (SRL)

Skala yang digunakan dalam penelitian ini adalah skala likert, skala ini digunakan untuk mengukur pendapat, sikap dan persepsi seseorang tentang suatu kejadian. Aspek-aspek yang dijadikan indicator untuk mengetahui SRL adalah sebagaimana tertera dalam table berikut:

Tabel 1.2

Rancangan Skala SRL

\begin{tabular}{|l|l|l|c|}
\hline No & Aspek-aspek & No Item & Jumlah \\
\hline 1 & Penetapan tujuan & $1,2,3$ & 3 \\
\hline
\end{tabular}




\begin{tabular}{|l|l|l|c|}
\hline 2 & Perencanaan & $4,5,6,7$ & 4 \\
\hline 3 & Motivasi diri & $8,9,10,11,12$ & 5 \\
\hline 4 & Kontrol atensi & $13,14,15$ & 3 \\
\hline 5 & Strategi & $16,17,18,19,20,21$ & 6 \\
\hline 6 & Monitor diri & $22,23,24,25$ & 4 \\
\hline 7 & $\begin{array}{l}\text { pencarian bantuan yang } \\
\text { tepat }\end{array}$ & 26,27 & 2 \\
\hline 8 & Evaluasi diri Jumlah & $28,29,30$ & 3 \\
\hline \multicolumn{2}{|l|}{ Jum } \\
\hline
\end{tabular}

2) Skala Kemandirian Belajar

Skala yang digunakan dalam penelitian ini adalah skala likert, skala ini digunakan untuk mengukur pendapat, sikap dan persepsi seseorang tentang suatu kejadian. Aspek-aspek yang dijadikan indikator untuk mengetahui kemandirian belajar adalah sebagaimana tertera dalam tabel berikut:

Tabel 1.3

Rancangan Skala Kemandirian Belajar

\begin{tabular}{|c|c|c|c|}
\hline No & Aspek-aspek & No Item & Jumlah \\
\hline 1 & Bebas & $1,2,3,4,5,6$, & 6 \\
\hline 2 & Progressif dan aktif & $7,8,9,10,11,12$ & 6 \\
\hline 3 & Inisiatif & $13,14,15,16,17,18$ & 6 \\
\hline 4 & Pengendalian diri & $19,20,21,22,23,24$ & 6 \\
\hline 5 & Kemantapan diri & $25,26,27,28,29,30$ & 6 \\
\hline \multicolumn{2}{|c|}{ Jumlah } & 30 \\
\hline
\end{tabular}

Penelitian ini menggunakan lima alternative jawaban, yaitu: sangat setuju (SS), setuju (S), tidak setuju (TS), dan sangat tidak setuju (STS). Skor jawaban berkisar antara 1 sampai 4 . Kriteria pemberian nilai meliputi: untuk jawaban sangat setuju (SS) mendapat nilai 4, jawaban setuju (S) mendapat nilai 3, jawaban tidak setuju (TS) mendapat nilai 2, jawaban sangat tidak setuju (STS) mendapat nilai 1.

Teknik analisis data yang digunakan pada penelitian ini menggunakan analisis statistik korelasi ganda dengan menggunakan program statistik SPSS versi 22,00. Adapun sebelum mengerjakan analisis data penelitian, peneliti melakukan uji instrument data, uji persyaratan instrument, dan pengujian hipotesis.

\section{LANDASAN TEORI}

\section{A. Self-Regulated Learning}

1. Pengertian Self-Regulated Learning

Secara harfiah self-regulated learning terdiri atas dua kata yaitu self-regulated dan learning. Self-regulated berarti terkelola, sedangkan learning berarti belajar. Zimmerman (dikutip Nugroho, 2004 : 7) menyatakan bahwa self-regulated learning adalah kesanggupan siswa 
secara personal untuk merancang sendiri strategi belajar dalam upaya meningkatkan pencapaian hasil belajar dan kesanggupannya untuk mengelola lingkungan yang kondusif untuk belajar.

Menurut Zimmerman (dikutip Anita, 2009 : 130) self-regulated merupakan proses yang digunakan untuk mengaktifkan dan mempertahankan pikiran, perilaku, dan emosi kita untuk mencapai tujuan kita. Tujuan tersebut berkaitan dengan proses belajar, maka disebut dengan self-regulated learning.

Bandura (dikutip Suminarti \& Fatimah, 2015 : 144) mendefinisikan self-regulated learning sebagai suatu keadaan dimana individu yang belajar sebagai pengendali aktivitas belajarnya sendiri, memonitor motivasi dan tujuan akademik, mengelola sumber daya manusia dan benda, serta menjadi perilaku dalam proses pengambilan keputusan dan pelaksana dalam proses belajar

2. Aspek-aspek Self-Regulated Learning

Secara khusus pembelajaran yang diatur sendiri (self-regulated learning) mencakup aspek-aspek sebagai berikut: 1) Penetapan Tujuan (Goal Setting), 2) Perencanaan (Planning), 3) Motivasi Diri (Self Motivation), 4) Kontrol Atensi (Attention Control), 5) Penggunaan Strategi Belajar Yang Fleksibel (Fleksibel Use Of Learning Strategies), 6) Monitor Diri (Self Monitoring), 7) Mencari Bantuan Yang Tepat (Appropiate Help Seeking), 8) Evaluasi Diri (Self Evaluation) (Jeanne, 2009 : 38).

\section{B. Kemandirian Belajar}

Kemandirian berasal dari kata mandiri yang artinya berdiri sendiri tanpa bergantung pada orang lain (KBBI, 2005 : 710). Istilah mandiri telah banyak dibicarakan orang. Istilah mandiri ini mempunyai ruang lingkup yang amat luas. Dalam hal ini diorientasikan pada kemandirian belajar. Menurut Sukarman Purba, kemandirian belajar tampak dalam usaha untuk menyadari serta memilih tujuan belajar, mendalami bahan pelajaran, keteraturan dan kedisiplinan dalam belajar, kritis dan taktis dalam menggunakan metode serta sarana, percaya diri dan optimis terhadap hasil yang dicapai, bersikap realistis serta bertanggung jawab (Sukarman, $1992: 16$ ).

Kemandirian dalam belajar adalah usaha siswa yang mengarah pada kesadaran belajar atas prakarsa sendiri dan segala keputusan serta masalah yang berkaitan dengan belajar diusahakan secara mandiri sehingga tanggung jawab sepenuhnya berada pada siswa, kemandirian dalam belajar berarti mengambil posisi dalam kegiatan dan seluk beluk kegiatan (tujuan, bahan, cara, dan sasaran belajar) (Maemun, 2008 : 10).

\section{Prestasi Belajar Bahasa Arab}

Prestasi adalah suatu kegiatan yang telah dikerjakan, diciptakan baik secara individual atau kelompok. Dalam Kamus Besar Bahasa Indonesia (KBBI, 2005 : 787), yang dimaksud dengan prestasi adalah hasil 
yang telah dicapai (dilakukan, dikerjakan, dan sebagainya.) Prestasi adalah apa yang telah dapat diciptakan, hasil pekerjaan, hasil yang menyenangkan hati yang diperoleh dengan jalan keuletan kerja.

Menurut Sumadi Suryabrata, menyatakan bahwa "Prestasi adalah nilai yang merupakan bentuk perumusan akhir yang diberikan oleh guru terkait dengan kemajuan belajar siswa selama waktu tertentu" (Sumadi, 2006 : 297). Sementara Muhibbin Syah menyatakan bahwa, "Prestasi sebagai tingkat keberhasilan siswa dalam mencapai tujuan yang ditetapkan dalam sebuah program" (Muhibbin, 2008 : 141).

Menurut M. Dalyono mengungkapkan bahwa "Belajar adalah suatu usaha atau kegiatan yang bertujuan mengadakan perubahan di dalam diri seseorang, mencakup perubahan tingkah laku, sikap kebiasaan, ilmu pengetahuan, keterampilan, dan sebagainya" (Dalyono, 2009 : 49).

\section{Hipotesis Penelitian}

Berdasarkan landasan teori dan argumentasi pada kerangka berpikir sebagaimana telah diuraikan di atas, maka dapat diajukan hipotesis $\left(\mathrm{H}_{0}\right)$ sebagai berikut:

1. Terdapat pengaruh positif dan signifikan antara self-regulated learning dengan prestasi Belajar Bahasa Arab siswa kelas X MA Mu'allimat Muhammadiyah, Yogyakarta.

2. Terdapat pengaruh positif dan signifikan antara kemandirian belajar dengan prestasi Belajar Bahasa Arab siswa kelas X MA Mu'allimat Muhammadiyah, Yogyakarta.

3. Terdapat pengaruh positif dan signifikan antara self-regulated learning dan kemandirian belajar terhadap prestasi belajar bahasa Arab siswa kelas X MA Mu'allimat Muhammadiyah, Yogyakarta.

\section{PEMBAHASAN}

Untuk mengetahui tentang self-regulated learning dan kemandirian belajar siswi digunakan angket (kuesioner) sebagai sumber data primer. Angket yang disebar berjumlah 120 dan angket kembali berjumlah 112 angket karena terdapat 4 siswi yang ikut kegiatan lomba, 2 siswi sakit dan 2 siswi kelas E yang keluar. Angket diisi oleh 112 responden. Setelah angket diisi oleh siswi, kemudian dilakukan perhitungan angket.

\section{A. Uji Instrumen Setiap Variabel}

\section{Uji Validitas}

Uji validitas item dilakukan dengan menggunakan rumus product moment. Perhitungan menggunakan bantuan SPSS 22,00 for windows. Angket berjumlah 30 diujikan pada 112 responden. Setiap responden diminta mengisi angket yang mencakup beberapa variabel, yakni variabel self-regulated learning 30 item dan variabel kemandirian belajar 30 item. Dari hasil uji validitas butir soal, terdapat 30 angket yang valid dengan taraf signifikan $5 \%(0,05)$ dalam lampiran. Angket 
yang diujikan terhitung valid semua, sehingga terdapat 30 angket yang digunakan dalam perhitungan selanjutnya.

Hasil Uji Coba Validitas Instrumen

\begin{tabular}{|c|c|c|c|c|c|c|c|}
\hline \multicolumn{5}{|c|}{$\mathrm{X}_{1}$} & \multicolumn{4}{|c|}{$\mathrm{X}_{2}$} \\
\hline No & $\mathrm{r}_{\text {hitung }}$ & No & $\mathrm{r}_{\text {hitung }}$ & No & $\mathrm{r}_{\text {hitung }}$ & No & $\mathrm{r}_{\text {hitung }}$ \\
\hline 1 & 0,452 & 16 & 0,439 & 1 & 0,291 & 16 & 0,294 \\
\hline 2 & 0,429 & 17 & 0,347 & 2 & 0,541 & 17 & 0,638 \\
\hline 3 & 0,509 & 18 & 0,220 & 3 & 0,499 & 18 & 0,492 \\
\hline 4 & 0,259 & 19 & 0,254 & 4 & 0,445 & 19 & 0,440 \\
\hline 5 & 0,564 & 20 & 0,310 & 5 & 0,516 & 20 & 0,586 \\
\hline 6 & 0,543 & 21 & 0,523 & 6 & 0,548 & 21 & 0,473 \\
\hline 7 & 0,313 & 22 & 0,301 & 7 & 0,472 & 22 & 0,622 \\
\hline 8 & 0,382 & 23 & 0,295 & 8 & 0,268 & 23 & 0,304 \\
\hline 9 & 0,550 & 24 & 0,253 & 9 & 0,524 & 24 & 0,359 \\
\hline 10 & 0,545 & 25 & 0,647 & 10 & 0,626 & 25 & 0,556 \\
\hline 11 & 0,425 & 26 & 0,453 & 11 & 0,273 & 26 & 0,667 \\
\hline 12 & 0,590 & 27 & 0,635 & 12 & 0,561 & 27 & 0,697 \\
\hline 13 & 0,309 & 28 & 0,572 & 13 & 0,502 & 28 & 0,755 \\
\hline 14 & 0,321 & 29 & 0,446 & 14 & 0,270 & 29 & 0,496 \\
\hline 15 & 0,525 & 30 & 0,659 & 15 & 0,586 & 30 & 0,680 \\
\hline
\end{tabular}

Hasil analisis hitung dengan menggunakan program SPSS tersebut kemudian dikonsultasikan dengan nilai $\mathrm{r}_{\text {tabel }}$ untuk $\mathrm{N}=112$ $(\mathrm{df}=\mathrm{n}-2=110)$ dengan signifikansi $5 \%(0,05)$ yakni sebesar 0,186. Setelah dikonsultasikan dengan $r_{\text {tabel }}$ ternyata $r_{\text {hitung }}>r_{\text {tabel. }}$ Dengan demikian $r_{\text {hitung }}$ lebih besar dari dari nilai $r_{\text {tabel }}$ maka seluruh item soal dari semua variabel dapat dikatakan valid atau layak dijadikan angket penelitian.

\section{Uji Reliabilitas}

Untuk menguji kedua instrument yang sudah valid, yaitu instrumen self-regulated learning dan variabel kemandirian belajar digunakan rumus Alpha Cronbach (Suharsimi, 2010 : 146). Sedangkan perhitungannya menggunakan bantuan SPSS versi 22,00. Hasil reliabilitas dapat dilihat pada lampiran 4, dapat dijelaskan sebagai berikut :
a. Self-regulated learning
Dari hasil perhitungan SPSS Alpha Cronbach terhadap 30 item pertanyaan tentang self-regulated learning di peroleh nilai Alpha sebesar 0,850 sedangkan nilai $r$ kritis (uji 2 sisi) pada signifikansi $5 \%$ dengan $\mathrm{n}=112(\mathrm{df}=\mathrm{n}-2=110)$ di dapat sebesar 0,186 maka instrumen variabel self-regulated learning dikatakan reliabel sebagai alat pengumpul data.

b. Kemandirian belajar 
Hasil perhitungan SPSS Alpha Cronbach terhadap 30 item pertanyaan tentang kemandirian belajar diperoleh skor 0,883 sedangkan nilai $r$ kritis (uji 2 sisi) pada signifikansi 5\% dengan $\mathrm{n}=112(\mathrm{df}=\mathrm{n}-2=110)$ di peroleh sebesar 0,186 maka instrument variabel kemandirian belajar dikatakan reliabel sebagai alat pengumpul data.

\section{B. B. Deskripsi Data Setiap Variabel}

1. Deskripsi Data Self-Regulated Learning

Dari analisis SPSS versi 22,00 dapat dilihat bahwa variabel selfregulated learning terdiri dari 30 item pertanyaan yang dijawab oleh 112 responden memiliki skor rata-rata (mean) 93,375 nilai tengah (median) 92 standar deviasi 5,6 nilai minimal 84 dan nilai maksimal 113.

Adapun analisis pengaruh self-regulated learning pada SPSS versi 22,00 adalah sebagai berikut :

Statistics
Self-Regulated Learning
X1
\begin{tabular}{|l|r|}
\hline \multicolumn{2}{|c|}{ Valid } \\
\multicolumn{1}{|c|}{ Missing } & 112 \\
Mean & 0 \\
Median & 93.3750 \\
Std. Deviation & 92.0000 \\
Range & 29.0283 \\
Minimum & 84.00 \\
Maximum & 113.00 \\
\hline
\end{tabular}

Untuk mengetahui derajat self-regulated learning siswi dibuat criteria yang terdiri atas 4 klasifikasi yaitu sangat setuju (SS), setuju (S), tidak setuju (TS), sangat tidak setuju (STS). Penetapan skor pada kriteria persepsi responden terhadap variabel yang diungkapkan didasarkan pada perkalian jumlah item dengan skor tertinggi pada alternatif jawaban item (30 x 4) dengan nilai harapan tertinggi 120 dan nilai harapan terendah 30 (30 x 1). Kemudian dilakukan perhitungan untuk membagi kategori self-regulated learning. Perhitungan yang dilakukan adalah sebagai berikut :

$$
\begin{array}{ll}
\text { Jumlah kelas }(\mathrm{K}) & =4 \\
\text { Range } & =\text { Nilai maksimum }- \text { Nilai minimum } \\
& =120-30=90 \\
\text { Interval } & =\mathrm{R} / \mathrm{K}=90 / 4=22,5=23
\end{array}
$$

Kategori Deskripsi Data

Pengaruh Self-Regulated Learning 


\begin{tabular}{|l|l|l|l|l|}
\hline No & Kategori & Skor & Responden & $\%$ \\
\hline 1 & Sangat Setuju & $97-120$ & 25 & 22,3 \\
\hline 2 & Setuju & $73-96$ & 87 & 77,7 \\
\hline 3 & Tidak Setuju & $49-72$ & 0 & 0 \\
\hline 4 & Sangat Tidak Setuju & $25-48$ & 0 & 0 \\
\hline \multicolumn{2}{|c|}{ Jumlah } & 112 & 100 \\
\hline
\end{tabular}

Berdasarkan tabel deskripsi data di atas, diketahui banyaknya siswi yang menganggap self-regulated learning ada pada kategori sangat setuju sebanyak 25 responden $(22,3 \%)$, setuju sebanyak 87 responden $(77,7 \%)$, tidak setuju 0 responden (0\%), dan sangat tidak setuju (0\%). Kemudian secara keseluruhan self-regulated learning siswi rata-rata adalah sebesar 92,6. Hal ini menunjukkan bahwa kemandirian belajar siswi kelas X MA Mu'allimat Muhammadiyah Yogyakarta dalam kaitannya dengan prestasi belajar bahasa Arab pada kategori baik yang ditunjukkan nilai rata-rata kemandirian belajar secara keseluruhan berada pada interval (73-96).

Dari jawaban responden atas item-item pernyataan pada variabel kemandirian belajar (X1) menunjukkan bahwa N (jumlah data) yang valid adalah sebanyak 112, sedangkan yang hilang (missing) adalah 0. Dengan demikian semua data dapat diproses secara keseluruhan.

2. Deskripsi Data Kemandirian Belajar

Dari analisis SPSS versi 22,00 dapat dilihat bahwa variabel selfregulated learning terdiri dari 30 item pertanyaan yang dijawab oleh 112 responden memiliki skor rata-rata (mean) 92,6 nilai tengah (median) 91 standar deviasi 4,8 nilai minimal 87 dan nilai maksimal 112.

Adapun analisis pengaruh kemandirian belajar pada SPSS versi 22,00 adalah sebagai berikut :

\begin{tabular}{|l|r|}
\multicolumn{2}{c}{ Statistics } \\
Kemandirian Belajar \\
\begin{tabular}{|lr|r} 
X2 & Valid & 112 \\
\multicolumn{1}{|c}{ Missing } & 0 \\
Mean & 92.6429 \\
Median & 91.0000 \\
Std. Deviation & 4.83951 \\
Range & 25.00 \\
Minimum & 87.00 \\
Maximum & 112.00 \\
\hline
\end{tabular}
\end{tabular}




$$
\begin{array}{ll}
\text { Jumlah kelas }(\mathrm{K}) & =4 \\
\text { Range } & =\text { Nilai maksimum }- \text { Nilai minimum } \\
& =120-30=90 \\
\text { Interval } & =\mathrm{R} / \mathrm{K}=90 / 4=22,5=23
\end{array}
$$

Kategori Deskripsi Data

Sinergitas Kemandirian Belajar

\begin{tabular}{|l|l|l|l|l|}
\hline No & Kategori & Skor & Responden & $\%$ \\
\hline 1 & Sangat Setuju & $97-120$ & 15 & $13,4 \%$ \\
\hline 2 & Setuju & $73-96$ & 97 & $86,6 \%$ \\
\hline 3 & Tidak Setuju & $49-72$ & 0 & 0 \\
\hline 4 & Sangat Tidak Setuju & $25-48$ & 0 & 0 \\
\hline \multicolumn{2}{|c|}{ Jumlah } & 112 & 100 \\
\hline
\end{tabular}

Sumber : Output Program SPSS Versi 22,00 tahun 2016

Berdasarkan tabel deskripsi data di atas, diketahui banyaknya siswi yang menganggap kemandirian belajar ada pada kategori sangat setuju sebanyak 15 responden $(13,4 \%)$, setuju sebanyak 97 responden $(86,6 \%)$, tidak setuju 0 responden (0\%), dan sangat tidak setuju $(0 \%)$. Kemudian secara keseluruhan kemandirian belajar siswi rata-rata adalah sebesar 92,6. Hal ini menunjukkan bahwa kemandirian belajar siswi kelas X MA Mu'allimat Muhammadiyah Yogyakarta dalam kaitannya dengan prestasi belajar bahasa Arab pada kategori baik yang ditunjukkan nilai rata-rata kemandirian belajar secara keseluruhan berada pada interval (73-96).

Dari jawaban responden atas item-item pernyataan pada variabel kemandirian belajar $\left(\mathrm{X}_{2}\right)$ menunjukkan bahwa $\mathrm{N}$ (jumlah data) yang valid adalah sebanyak 11, sedangkan yang hilang (missing) adalah 0 . Dengan demikian semua data dapat diproses secara keseluruhan.

3. Deskripsi Data Prestasi Belajar

Prestasi belajar ini merupakan prestasi belajar mata pelajaran bahasa Arab yang diukur dengan nilai UAS (Ulangan Akhir Semester) karena siswi dianggap dapat mengelola self-regulated learning dan kemandirian belajar. Nilai tertinggi bahasa Arab adalah 100 dan nilai terendahnya adalah 0 .

Statistics

Prestasi Belajar

\begin{tabular}{|ll|r|}
\hline N & Valid & 112 \\
& Missing & 3 \\
Mean & & 83.9464
\end{tabular}




\begin{tabular}{|l|r|} 
Median & 82.5000 \\
Std. Deviation & 4.27193 \\
Range & 16.00 \\
Minimum & 78.00 \\
Maximum & 94.00 \\
\hline
\end{tabular}

Analisis prestasi belajar bahasa Arab siswi dikategorikan ke dalam lima kategori, yaitu : sangat baik, baik, cukup, kurang, sangat kurang. Kemudian dilakukan perhitungan sebagai berikut :

$$
\begin{array}{ll}
\text { Jumlah kelas }(\mathrm{K}) & =5 \\
\text { Range } & =\text { Nilai maksimum - Nilai minimum } \\
& =100-0=100 \\
\text { Interval } & =\mathrm{R} / \mathrm{K}=100 / 5=20
\end{array}
$$

Tabel 4.7

Kategori Deskripsi Data

Prestasi Belajar

\begin{tabular}{|l|l|l|l|l|}
\hline No & Kategori & Skor & Responden & $\%$ \\
\hline 1 & Sangat baik & $81-100$ & 90 & $80,4 \%$ \\
\hline 2 & Baik & $61-80$ & 22 & $19,6 \%$ \\
\hline 3 & Cukup & $41-60$ & 0 & 0 \\
\hline 4 & Kurang & $21-40$ & 0 & 0 \\
\hline 5 & Sangat kurang & $0-20$ & 0 & 0 \\
\hline \multicolumn{2}{|c|}{ Jumlah } & 112 & $100 \%$ \\
\hline
\end{tabular}

Gambaran peningkatan prestasi belajar mata pelajaran bahasa Arab dapat divisualisasikan sebagai berikut :

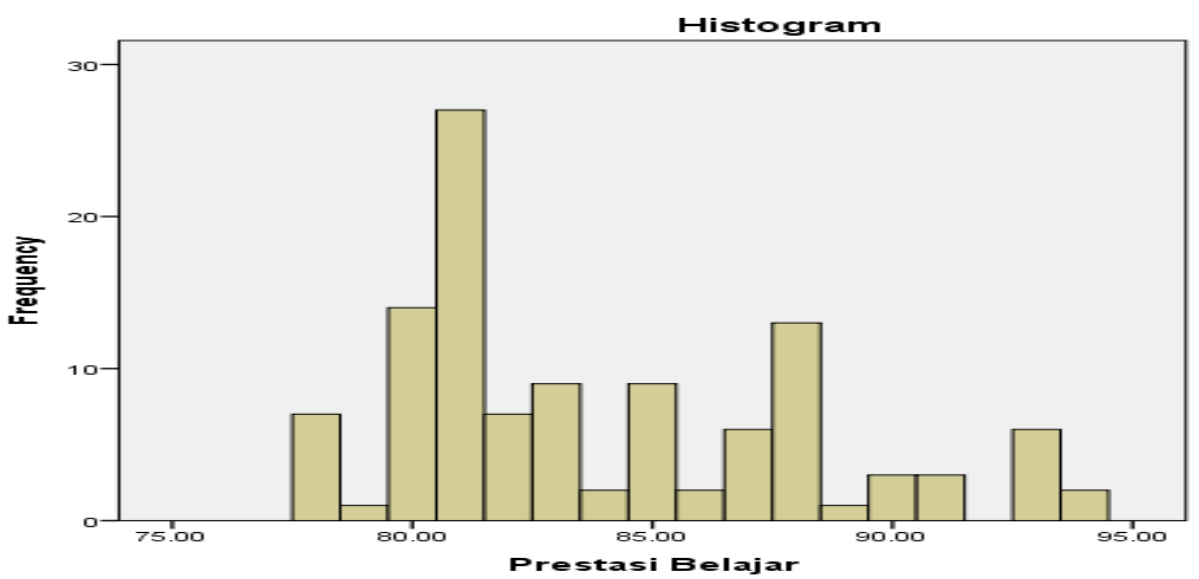


Berdasarkan tabel dan histogram di atas, diketahui mayoritas siswi kelas X MA Mu'allimat Muhammadiyah Yogyakarta memiliki prestasi belajar dalam kategori sangat kurang tidak ada $(0 \%)$, kategori kurang tidak ada (0\%), kategori cukup tidak ada (0\%), kategori baik sebanyak 22 siswi (19,6\%), kategori sangat baik sebanyak 90 siswi $(80,4 \%)$. Kemudian secara keseluruhan prestasi belajar siswi rata-rata secara keseluruhan berada pada interval (81-100).

\section{Uji Persyaratan Analisis Regresi}

1. Uji Normalitas

Uji Normalitas dilakukan pada variabel self-regulated, kemandirian belajar, dan prestasi belajar siswi dengan menggunakan korelasi parametrik Kolmogorov-Smirnov dan Shapiro-Wilk.

Adapun langkah-langkahnya sebagai berikut.

Uji Normalitas Kolmogorov-Smirnov dan Shapiro-Wilk

Untuk menguji kenormalan data hasil penelitian digunakan uji Kolmogorov-Smirnov dan Shapiro-Wilk dengan bantuan SPSS 22,00. Hipotesisnya adalah.

$\mathrm{H}_{0}=$ Data berdistribusi normal

$\mathrm{H}_{1}=$ Data berdistribusi tidak normal

Dasar pengambilan keputusan dalam uji normalitas adalah :

a. Jika Sig. (Signifikansi) $<0,05$ maka data berdistribusi tidak normal

b. Jika Sig. (Signifikansi) > 0,05 maka data berdistribusi normal

Tabel 4.8

Tests of Normality

\begin{tabular}{|l|r|r|r|r|r|r|}
\hline & \multicolumn{3}{|c|}{ Kolmogorov-Smirnov } & \multicolumn{3}{|c|}{ Shapiro-Wilk } \\
\cline { 2 - 7 } & Statistic & \multicolumn{1}{c|}{ Df } & \multicolumn{1}{c|}{ Sig. } & Statistic & \multicolumn{1}{c|}{ Df } & \multicolumn{1}{c|}{ Sig. } \\
\hline selfregulated & .113 & 112 & .205 & .034 & 112 & \\
kemandirianbl & .135 & 112 & .233 & .045 & 112 & \\
jar & .142 & 112 & .344 & .029 & 112 &. \\
prestasibljar & & & & & \\
\hline
\end{tabular}

a. Lilliefors Significance Correction

$>$ Tabel di atas menunjukkan hasil analisis uji normalitas terhadap ketiga variabel diatas untuk Kolmogorov-Smirnov dan Shapiro-Wilk.

$>$ Berdasarkan hasil analisis pada kolom sig untuk Kolmogorov Smirnov angka yang muncul adalah 0,205 (self-regulated learning), 0,233 (kemandirian belajar), dan 0,344 (prestasi belajar). Dapat disimpulkan bahwa ketiga variabel memiliki nilai sig > 0,05 yang berarti data berdistribusi normal.

$>$ Pada kolom sig untuk Shapiro-Wilk, tidak memunculkan hasil, yang berarti model ini tidak bisa dianalisis menggunakan cara Shapiro-Wilk.

2. Uji Linearitas

Uji linearitas bertujuan untuk mengetahui apakah variabel bebas dengan variabel terikat mempunyai pengaruh yang linear secara signifikan. Uji ini digunakan sebagai prasyarat statistic parametric 
khususnya dalam analisis korelasi atau regresi linear yang termasuk dalam hipotesis assosiatif. Pada program SPSS 22,00 uji linearitas menggunakan Test for Linearity pada taraf signifikan 0,05.

Dasar pengambilan keputusan :

$>$ Jika

Nilai probabilitas $>0,05$

(Sig dari Deviation Of Linearity)

Nilai signifikansi $<0,05$

(Sig dari Linearity)

Maka pengaruh antara variabel X dan Y adalah linear

$>$ Jika

Nilai probabilitas $<0,05 \quad$ (Sig dari Deviation Of Linearity)

Nilai signifikansi $>0,05$

(Sig dari Linearity)

Maka pengaruh antara variabel X dan $\mathrm{Y}$ adalah tidak linear

Pengambilan keputusan dilakukan dengan ketentuan jika probabilitas lebih besar dari 0,05 atau $\rho>0,05$ maka $\mathrm{H}_{0}$ diterima, dan jika probabilitas lebih kecil dari 0,05 atau $\rho<0,05$ maka $\mathrm{H}_{0}$ ditolak.

Hasil uji linearitas dapat dilihat pada lampiran regresi yang dirangkum sebagaimana table di bawah ini.

ANOVA Table

\begin{tabular}{|c|c|c|c|c|c|c|c|}
\hline & & & $\begin{array}{c}\text { Sum of } \\
\text { Squares }\end{array}$ & Df & $\begin{array}{c}\text { Mean } \\
\text { Square }\end{array}$ & $\mathrm{F}$ & Sig. \\
\hline \multirow{5}{*}{$\begin{array}{l}\text { Self- } \\
\text { regulated } \\
* \text { Prestasi } \\
\text { Belajar }\end{array}$} & \multirow{3}{*}{$\begin{array}{l}\text { Between } \\
\text { Groups }\end{array}$} & (Combined) & 904.748 & 14 & 64.625 & 2.400 & .006 \\
\hline & & Linearity & 357.498 & 1 & 357.498 & $\begin{array}{r}13.27 \\
9\end{array}$ & .000 \\
\hline & & $\begin{array}{l}\text { Deviation from } \\
\text { Linearity }\end{array}$ & 547.250 & 13 & 42.096 & 1.564 & .102 \\
\hline & \multicolumn{2}{|c|}{ Within Groups } & 2611.502 & 97 & 26.923 & & \\
\hline & \multicolumn{2}{|l|}{ Total } & 3516.250 & 111 & & & \\
\hline \multirow{5}{*}{$\begin{array}{l}\text { Kemandiri } \\
\text { an Belajar } \\
\text { * Prestasi } \\
\text { Belajar }\end{array}$} & Between & (Combined) & 685.328 & 14 & 48.952 & 2.480 & .005 \\
\hline & Groups & Linearity & 150.473 & 1 & 150.473 & 7.624 & .007 \\
\hline & & $\begin{array}{l}\text { Deviation from } \\
\text { Linearity }\end{array}$ & 534.855 & 13 & 41.143 & 2.085 & .109 \\
\hline & \multicolumn{2}{|c|}{ Within Groups } & 1914.387 & 97 & 19.736 & & \\
\hline & \multicolumn{2}{|l|}{ Total } & 2599.714 & 111 & & & \\
\hline
\end{tabular}

Dari tabel di atas menunjukkan masing-masing pengaruh antara selfregulated learning dan kemandirian belajar dengan prestasi belajar bahasa Arab siswi MA Mu'allimat Muhammadiyah Yogyakarta.

$>$ Pada Anova Tabel, self-regulated * Prestasi Belajar baris Linearity dan Deviation From Linearity

Signifikansi $=0,000<0,05$

Probabilitas $=0,102>0,05$

Maka pengaruh antara variabel $\mathrm{X}_{1}$ (self-regulated) dan $\mathrm{Y}$ (prestasi belajar) adalah linear. 
Pada Anova Table, kemandirian belajar * Prestasi Belajar baris Linearity dan Deviation From Linearity

Signifikansi $=0,007<0,05$

Probabilitas $=0,109>0,05$

Maka pengaruh antara variabel $\mathrm{X}_{2}$ (kemandirian belajar) dan $\mathrm{Y}$ (prestasi belajar) adalah linear

Dari hasil penelitian pengaruh antara variabel bebas (independent) masing-masing bersifat linear terhadap variabel dependent. Jadi pengaruh antara self-regulated dan kemandirian belajar dengan prestasi belajar tidak menyimpang dari persamaan linear artinya memiliki pengaruh yang linear.

\section{Uji Homogenitas}

Uji homogenitas dilakukan terhadap data angket self-regulated, kemandirian belajar dan prestasi belajar bahasa Arab siswi, karena uji ini untuk mengetahui variansi populasi. Perhitungan dilakukan dengan menggunakan bantuan SPSS 22,00.

Test of Homogeneity of Variances

prestasibljar

\begin{tabular}{|r|r|r|c|}
\hline $\begin{array}{c}\text { Levene } \\
\text { Statistic }\end{array}$ & \multicolumn{1}{|c|}{ df1 } & df2 & Sig. \\
\hline .081 & 17 & 109 & .614 \\
\hline
\end{tabular}

Test of Homogeneity of Variances

Self-regulated

\begin{tabular}{|r|r|r|c|}
\hline $\begin{array}{c}\text { Levene } \\
\text { Statistic }\end{array}$ & df1 & df2 & \multicolumn{1}{c|}{ Sig. } \\
\hline .062 & 10 & 97 & .210 \\
\hline
\end{tabular}

Test of Homogeneity of Variances

\begin{tabular}{|c|c|c|c|}
\hline \multicolumn{4}{|c|}{ Kemandirian Belajar } \\
\hline $\begin{array}{l}\text { Levene } \\
\text { Statistic }\end{array}$ & df1 & $\mathrm{df} 2$ & Sig. \\
\hline .070 & 10 & 97 & .413 \\
\hline
\end{tabular}

Jika nilai sig. $<0,05$ maka varian dari dua atau lebih kelompok populasi data adalah tidak homogen atau tidak sama.

$>$ Jika nilai sig. > 0,05 maka varian dari dua atau lebih kelompok populasi data adalah homogen atau sama.

Pengambilan keputusan didapat dari tabel dengan taraf signifikansi 0,05. Variabel prestasi belajar $(0,614>0,05)$, variabel selfregulated $(0,210>0,05)$ dan variabel kemandirian belajar $(0,413>$ $0,05)$ yang artinya data berada pada varian yang sama atau homogen.

4. Uji Hipotesis

Tujuan dari uji hipotesis adalah untuk menguji dan memperoleh gambaran mengenai pengaruh variabel bebas terhadap variabel terikat. 
Jika hipotesis awal (hipotesis nihil) dari hasil uji dinyatakan diterima dan menolak hipotesis kedua (hipotesis alternatif) berarti yang benar adalah pernyataan awal. Namun sebaliknya hipotesis awal dinyatakan ditolak dan hipotesis kedua diterima, berarti pernyataan awal tidak benar, yang benar pernyataan kedua. (Danang, 2012 : 1). Analisis dilakukan dengan menggunakan bantuan program SPSS 22,00 for windows.

Analisis regresi untuk pengujian hipotesis dapat dilihat pada lampiran regresi linear yang penjelasannya sebagai berikut.

1) Uji Pengaruh Self-regulated Learning Terhadap Prestasi Belajar Bahasa Arab

Hipotesis: $\mathrm{H}_{0}=$ tidak ada pengaruh yang signifikan antara selfregulated learning terhadap prestasi belajar bahasa Arab. $\mathrm{H}_{\mathrm{a}}=$ ada pengaruh yang signifikan antara self-regulated learning terhadap prestasi belajar bahasa Arab.

Hasil Uji t $\mathrm{X}_{1}$ terhadap Y

\section{Coefficients $^{\mathbf{a}}$}

\begin{tabular}{|c|c|c|c|c|c|c|}
\hline \multirow{2}{*}{\multicolumn{2}{|c|}{ Model }} & \multicolumn{2}{|c|}{$\begin{array}{l}\text { Unstandardized } \\
\text { Coefficients }\end{array}$} & \multirow{2}{*}{$\begin{array}{c}\begin{array}{c}\text { Standardize } \\
\text { d } \\
\text { Coefficients }\end{array} \\
\text { Beta }\end{array}$} & \multirow[b]{2}{*}{ l } & \multirow[b]{2}{*}{ Sig. } \\
\hline & & B & Std. Error & & & \\
\hline 1 & (Constant) & 61.511 & 5.919 & & 10.393 & .000 \\
\hline & $\begin{array}{l}\text { Self- } \\
\text { regulated }\end{array}$ & .223 & .063 & .319 & 3.528 & .001 \\
\hline
\end{tabular}

a. Dependent Variable: Prestasi Belajar

Persamaan umum regresi linear sederhana $\mathrm{Y}=\mathrm{a}+\mathrm{bX}$ dimana:

$\mathrm{Y}=$ Subyek dalam variabel bebas yang prediksi

$\mathrm{a}=$ Harga $\mathrm{Y}$ bila $\mathrm{X}=0$ (harga konstan)

$\mathrm{b}=$ angka arah atau koefisien regresi yang menunjukkan angka peningkatan ataupun penurun variabel terikat yang didasarkan pada variabel bebas. Bila b (+) maka naik, dan bila bila (-) maka terjadi penurunan.

Dasar pengambilan keputusannya adalah :

$>$ Jika Sig $<\alpha(0,05) \mathrm{H}_{0}$ ditolak dan $\mathrm{H}_{\mathrm{i}}$ diterima, yang artinya model linear signifikan.

Jika Sig $>\alpha(0,05) \mathrm{H}_{0}$ diterima dan $\mathrm{H}_{\mathrm{i}}$ ditolak, yang artinya model linear tidak signifikan.

Tabel output coefficient memaparkan nilai-nilai yang diperlukan dalam rumus $\mathrm{Y}=\mathrm{a}+\mathrm{bX}$

Data diambil dari kolom Unstandardized Coefficients bagian B.

Nilai a Constanta adalah 61,511, dengan sig sebesar $0,000<\alpha 0,05$, maka konstanta a signifikan. 
Nilai b Variabel Independent Self-regulated Learning $\left(\mathrm{X}_{1}\right)$ adalah 0,223 dengan sig 0,001 $<\alpha$ 0,05 maka b Signifikan, $\mathrm{H}_{0}$ ditolak dan $\mathrm{H}_{\mathrm{i}}$ diterima.

Maka dapat ditulis menjadi persamaan $\mathrm{Y}=61,511+0,223 \mathrm{X}$. Hal ini menunjukkan ada pengaruh positif antara variabel self-regulated learning $\left(\mathrm{X}_{1}\right)$ terhadap prestasi belajar bahasa Arab.

\begin{tabular}{|c|c|c|c|c|c|c|}
\hline \multicolumn{7}{|c|}{$\begin{array}{c}\text { Hasil Uji F X } \text { X }_{1} \text { terhadap Y } \\
\text { ANOVA }^{\mathbf{a}}\end{array}$} \\
\hline \multicolumn{2}{|c|}{ Model } & $\begin{array}{l}\text { Sum of } \\
\text { Squares }\end{array}$ & $\mathrm{df}$ & $\begin{array}{l}\text { Mean } \\
\text { Square }\end{array}$ & $\mathrm{F}$ & Sig. \\
\hline \multirow[t]{3}{*}{1} & Regression & 175.251 & 1 & 175.251 & 12.449 & $.001^{b}$ \\
\hline & Residual & 1548.46 & 110 & 14.077 & & \\
\hline & Total & 1723.714 & 111 & & & \\
\hline
\end{tabular}

a. Dependent Variable: Prestasi Belajar

b. Predictors: (Constant), Self-regulated

Berdasarkan tabel hasil uji $\mathrm{F}$ tersebut dapat dijelaskan bahwa pada tabel anova diperoleh skor koefisien regresi $\mathrm{F}$ sebesar 12.449 dan skor probabilitas (sig) 0,001. Besaran probabilitas ternyata lebih kecil dibandingkan dengan $\alpha=0,05$ atau $\rho=0,001<\alpha=0,05$ maka koefisien regresi adalah signifikan.

Hasil Uji Koefisien $\mathrm{X}_{1}$ terhadap Y

Model Summary

\begin{tabular}{|l|l|r|r|c|}
\hline $\begin{array}{l}\text { Mode } \\
\mathrm{l}\end{array}$ & $\mathrm{R}$ & R Square & $\begin{array}{c}\text { Adjusted R } \\
\text { Square }\end{array}$ & $\begin{array}{c}\text { Std. Error of the } \\
\text { Estimate }\end{array}$ \\
\hline 1 & $.319^{\mathrm{a}}$ & .102 & .094 & 3.75193 \\
\hline
\end{tabular}

a. Predictors: (Constant), Self-regulated

Pada tabel summery diperoleh skor koefisien korelasi (R) sebesar 0,319 dan koefisien determinasi (R Square) sebesar 0,102.

Berarti $\mathrm{R}=0,319>\mathrm{R}$ Square 0,102. Hal ini menunjukkan ada pengaruh yang signifikan antara self-regulated learning terhadap prestasi belajar bahasa Arab siswi.

2) Uji Pengaruh Kemandirian Belajar Terhadap Prestasi Belajar Bahasa Arab

Hipotesis: $\mathrm{H}_{0}=$ tidak ada pengaruh yang signifikan antara kemandirian belajar siswi terhadap prestasi belajar bahasa Arab. $\mathrm{H}_{\mathrm{I}}$ = ada pengaruh yang signifikan antara kemandirian belajar siswi terhadap prestasi belajar bahasa Arab.

Hasil Uji t $\mathrm{X}_{2}$ terhadap Y

Coefficients $^{a}$

\begin{tabular}{|l|c|c|c|c|}
\hline Model & $\begin{array}{c}\text { Standardize } \\
\text { Unstandardized } \\
\text { Coefficients }\end{array}$ & $\begin{array}{c}\mathrm{d} \\
\text { Coefficients }\end{array}$ & $\mathrm{t}$ & $\mathrm{Sig}$. \\
\hline
\end{tabular}




\begin{tabular}{|l|r|r|r|r|r|}
\hline & \multicolumn{1}{|c|}{ B } & Std. Error & \multicolumn{1}{|c|}{ Beta } & & \\
\hline (Constant) & 64.208 & 6.991 & & 9.185 & .000 \\
Kemandirian & .196 & .075 & .241 & 2.600 & .011 \\
Belajar & & & & & \\
\hline
\end{tabular}

a. Dependent Variable: Prestasi Belajar

Persamaan umum regresi linear sederhana $\mathrm{Y}=\mathrm{a}+\mathrm{bX}$ dimana:

$\mathrm{Y}=$ Subyek dalam variabel bebas yang prediksi

$\mathrm{a}=$ Harga $\mathrm{Y}$ bila $\mathrm{X}=0$ (harga konstan)

$\mathrm{b}=$ angka arah atau koefisien regresi yang menunjukkan angka peningkatan ataupun penurun variabel terikat yang didasarkan pada variabel bebas. Bila b (+) maka naik, dan bila bila (-) maka terjadi penurunan.

Dasar pengambilan keputusannya adalah :

$>$ Jika Sig $<\alpha(0,05) \mathrm{H}_{0}$ ditolak dan $\mathrm{H}_{\mathrm{i}}$ diterima, yang artinya model linear signifikan.

$>$ Jika Sig $>\alpha(0,05) \mathrm{H}_{0}$ diterima dan $\mathrm{H}_{\mathrm{i}}$ ditolak, yang artinya model linear tidak signifikan.

Tabel output coefficient memaparkan nilai-nilai yang diperlukan dalam rumus $\mathrm{Y}=\mathrm{a}+\mathrm{bX}$

Data diambil dari kolom Unstandardized Coefficients bagian B.

Nilai a Constanta adalah 64.208, dengan sig sebesar 0,000< $\alpha 0,05$, maka konstanta a signifikan.

Nilai b Variabel Independent Kemandirian Belajar $\left(\mathrm{X}_{2}\right)$ adalah 0,196 dengan sig 0,011< $\alpha$ 0,05 maka b Signifikan, $\mathrm{H}_{0}$ ditolak dan $\mathrm{H}_{\mathrm{i}}$ diterima.

Maka dapat ditulis menjadi persamaan $Y=64.208+0,196 \mathrm{X}$. Hal ini menunjukkan ada pengaruh positif antara variabel kemandirian belajar $\left(\mathrm{X}_{2}\right)$ terhadap prestasi belajar bahasa Arab.

Hasil Uji F X 2 terhadap Y

ANOVAa

\begin{tabular}{|c|c|c|c|c|c|c|}
\hline \multicolumn{2}{|c|}{ Model } & $\begin{array}{c}\text { Sum of } \\
\text { Squares }\end{array}$ & df & Mean Square & $F$ & Sig. \\
\hline 1 & $\begin{array}{l}\text { Regressio } \\
n\end{array}$ & 99.769 & 1 & & $\begin{array}{r}6.75 \\
8\end{array}$ & $.011^{\mathrm{b}}$ \\
\hline & Residual & 1623.945 & 110 & 14.763 & & \\
\hline & Total & 1723.714 & 111 & & & \\
\hline
\end{tabular}

a. Dependent Variable: Prestasi Belajar

b. Predictors: (Constant), Kemandirian Belajar

Berdasarkan tabel hasil uji $\mathrm{F}$ tersebut dapat dijelaskan bahwa pada tabel anova diperoleh skor koefisien regresi $\mathrm{F}$ sebesar 99,769 dan skor probabilitas (sig) 0,011. Besaran probabilitas ternyata lebih kecil dibandingkan dengan $\alpha=0,05$ atau $\rho=0,011<\alpha=0,05$ maka koefisien regresi adalah signifikan, sehingga model regresi 
dapat digunakan untuk memprediksi prestasi belajar bahasa Arab siswi.

Hasil Uji Koefisien $\mathrm{X}_{2}$ terhadap Y

Model Summary

\begin{tabular}{|l|l|r|r|r|}
\hline $\begin{array}{l}\text { Mode } \\
\mathrm{l}\end{array}$ & $\mathrm{R}$ & R Square & $\begin{array}{c}\text { Adjusted R } \\
\text { Square }\end{array}$ & $\begin{array}{r}\text { Std. Error of } \\
\text { the Estimate }\end{array}$ \\
\hline 1 & $.241^{\mathrm{a}}$ & .058 & .049 & 3.84228 \\
\hline
\end{tabular}

a. Predictors: (Constant), Kemandirian Belajar

Pada tabel summery diperoleh skor koefisien korelasi (R) sebesar 0,241 dan koefisien determinasi (R Square) sebesar 0,058

Berarti $\mathrm{R}=0,241>\mathrm{R}$ Square 0,058. Hal ini menunjukkan ada pengaruh yang signifikan antara kemandirian belajar terhadap prestasi belajar bahasa Arab siswi.

3) Uji Pengaruh Self-regulated Learning dan Kemandirian Belajar Terhadap Prestasi Belajar Bahasa Arab

Pengujian hipotesis ganda pada penelitian ini bertujuan untuk mengetahui pengaruh yang signifikan antara self-regulated learning dan kemandirian belajar terhadap prestasi belajar bahasa Arab.

Hipoteis $\mathrm{H}_{0}$ = tidak ada pengaruh yang signifikan antara selfregulated learning dan kemandirian belajar terhadap prestasi belajar bahasa Arab. $\mathrm{H}_{\mathrm{I}}=$ ada pengaruh yang signifikan antara selfregulated learning dan kemandirian belajar terhadap prestasi belajar bahasa Arab.

Persamaan umum regresi linear berganda $\mathrm{Y}=\mathrm{a}+\mathrm{b}_{1} \mathrm{X}_{1}+\mathrm{b}_{1} \mathrm{X}_{2}$, dimana :

$\mathrm{Y}=$ Subyek dalam variabel bebas yang prediksi

$\mathrm{a}=$ Harga $\mathrm{Y}$ bila $\mathrm{X}_{1}$ dan $\mathrm{X}_{2}=0$ (harga konstan)

$\mathrm{b}=$ angka arah atau koefisien regresi yang menunjukkan angka peningkatan ataupun penurun variabel terikat yang didasarkan pada variabel bebas. Bila b (+) maka naik, dan bila bila (-) maka terjadi penurunan.

Hasil Uji t $\mathrm{X}_{1}$ dan $\mathrm{X}_{2}$ terhadap Y

Coefficients $^{\mathbf{a}}$

\begin{tabular}{|l|r|r|r|r|r|}
\hline & \multicolumn{1}{|c|}{$\begin{array}{c}\text { Standardiz } \\
\text { ed } \\
\text { Model }\end{array}$} & $\begin{array}{c}\text { Unstandardized } \\
\text { Coefficients }\end{array}$ & $\begin{array}{c}\text { Coefficient } \\
\text { s }\end{array}$ & & \\
\cline { 2 - 4 } & \multicolumn{1}{|c|}{$\mathrm{B}$} & \multicolumn{1}{c|}{ Error } & Beta & \multicolumn{1}{c|}{ T } & Sig. \\
\hline (Constant) & 49.973 & 8.145 & & 6.136 & .000 \\
Self-regulated & .198 & .064 & .282 & 3.105 & .002 \\
Kemandirian & .150 & .074 & .185 & 2.031 & .045 \\
Belajar & & &
\end{tabular}


a. Dependent Variable: Prestasi Belajar

Dari perhitungan analisis regresi berganda pada tabel koefisien diperoleh skor konstan sebesar 49.973, skor arah regresi self-regulated learning $\left(\mathrm{X}_{1}\right)$ sebesar 0,198 dan skor arah regresi kemandirian belajar $\left(\mathrm{X}_{2}\right)$ sebesar 0,150. Berdasarkan konstan dan arah regresi tersebut maka persamaan garis regresinya adalah $\mathrm{Y}=49.973+0,198 \mathrm{X}_{1}+0,150 \mathrm{X}_{2}$.

Persamaan di atas dapat dikatakan bahwa prestasi belajar bahasa Arab tanpa didukung self-regulated dan kemandirian belajar (konstan) sebesar 49,973 dan setiap perubahan/ peningkatan secara bersama antara self-regulated dan kemandirian belajar $\left(\mathrm{X}_{1}\right.$ dan $\left.\mathrm{X}_{2}\right)$ akan menentukan tingkat prestasi belajar siswi,setiap ada kenaikan satu poin pada selfregulated learning yang mengakibatkan naiknya skor prestasi belajar siswi adalah sebesar 0,198 dan setiap ada kenaikan satu poin pada kemandirian belajar yang mengakibatkan naiknya skor prestasi belajar sebesar 0,150.

Pada standardized coefficients didapatkan angka beta untuk variabel self-regulated learning 0,282 dan variabel kemandirian belajar sebesar 0,185. Hal ini menunjukkan bahwa dari kedua variabel bebas (independent) yang paling berpengaruh terhadap prestasi belajar bahasa Arab adalah self-regulated learning $28,2 \%$ dibanding variabel kemandirian belajar sebesar 18,5\%. Hasil Uji F X $\mathrm{X}_{1}$ dan $\mathrm{X}_{2}$ terhadap $\mathrm{Y}$

ANOVA $^{\mathrm{a}}$

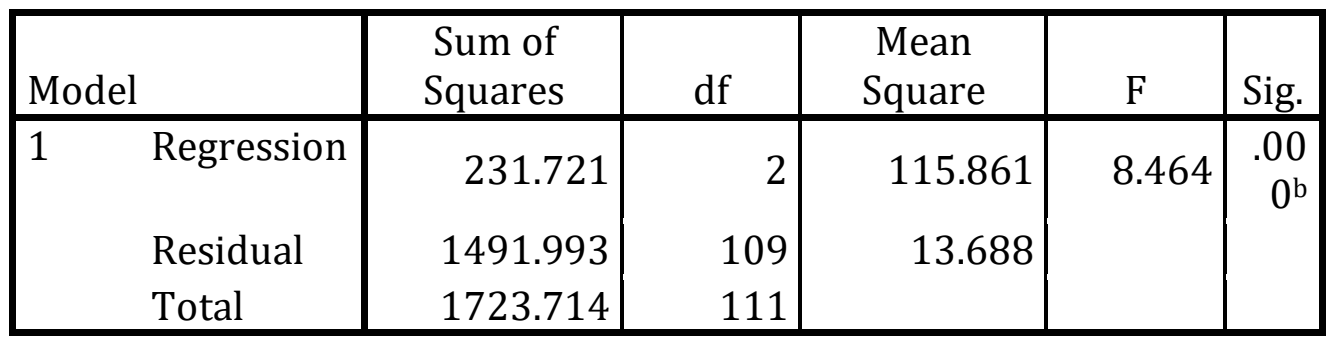

a. Dependent Variable: Prestasi Belajar

b. Predictors: (Constant), Kemandirian Belajar, Self-regulated

Uji F digunakan untuk menguji keberartian semua variabel bebas (independent) self-regulated learning $\left(\mathrm{X}_{1}\right)$ dan kemandirian belajar $\left(\mathrm{X}_{2}\right)$ secara bersama-sama terhadap variabel terikat (dependent) yaitu prestasi belajar siswi.

Berdasarkan perhitugan SPSS versi 21,00 diperoleh nilai $F_{\text {hitung }}=8,464$ dengan signifikansi $F$ sebesar 0,000. Dengan menggunakan tingkat signifikansi 0,05.

Dasar Pengambilan keputusannya adalah :

Jika Sig $<\alpha(0,05) \mathrm{H}_{0}$ ditolak dan $\mathrm{H}_{\mathrm{i}}$ diterima, yang artinya model linear signifikan.

$>$ Jika Sig $>\alpha(0,05) \mathrm{H}_{0}$ diterima dan $\mathrm{H}_{\mathrm{i}}$ ditolak, yang artinya model linear tidak signifikan. 
Regression menunjukkan Sig $0,000<\alpha(0,05)$ berarti $\mathrm{H}_{0}$ ditolak dan $\mathrm{H}_{\mathrm{i}}$ diterima, yang artinya ada pengaruh yang signifikan antara variabel self-regulated learning $\left(\mathrm{X}_{1}\right)$ dan kemnadirian belajar $\left(\mathrm{X}_{2}\right)$ terhadap prestasi belajar bahasa Arab siswi $(\mathrm{Y})$.

Hasil Uji Koefisien $\mathrm{X}_{1}$ dan $\mathrm{X}_{2}$ Terhadap Y

Model Summaryb

\begin{tabular}{|l|l|r|r|r|}
\hline Model & $\mathrm{R}$ & R Square & $\begin{array}{c}\text { Adjusted R } \\
\text { Square }\end{array}$ & $\begin{array}{r}\text { Std. Error of } \\
\text { the Estimate }\end{array}$ \\
\hline 1 & $.367^{\mathrm{a}}$ & .134 & .119 & 3.69973 \\
\hline
\end{tabular}

a. Predictors: (Constant), Kemandirian Belajar, Self-

regulated

b. Dependent Variable: Prestasi Belajar

Pada tabel summary diperoleh skor korelasi (R) sebesar 0,367

dan koefisien determinasi (R Square) sebesar 0,134.

Berarti $\mathrm{R}=0,367>\mathrm{R}$ Square 0,134. Hal ini menunjukkan ada pengaruh yang signifikan antara self-regulated learning dan kemandirian belajar terhadap prestasi belajar bahasa Arab siswi.

Skor adjusted $R$ square sebesar 0,119 yang berarti bahwa $(11,9 \%)$ prestasi belajar dipengaruhi oleh self-regulated learning dan kemandirian belajar, sedangkan selebihnya $(88,1 \%)$ prestasi hasil belajar dipengaruhi oleh variabel lain.

\section{Kesimpulan}

Berdasarkan uraian pada bab-bab sebelumnya, maka peneliti dapat memberikan kesimpulan pada penelitian ini terkait dengan pengaruh selfregulated learning dan kemandirian belajar terhadap prestasi belajar bahasa Arab pada siswa MA Mu'allimat Muhammadiyah Yogyakarta, yaitu sebagai berikut :

1. Deskripsi data variabel self-regulated learning siswi MA Mu'allimat Muhammadiyah Yogyakarta diketahui pada kategori sangat baik sebanyak 25 responden (22,3\%), kategori baik sebanyak 87 responden $(77,7 \%)$, kategori tidak baik dan sangat tidak baik 0\%. Sementara variabel kemandirian belajar siswi MA Mu'allimat Muhammadiyah Yogyakarta diketahui pada kategori sangat baik sebanyak 15 responden $(13,4 \%)$, kategori baik sebanyak 87 responden (86,6\%), kategori tidak baik dan sangat tidak baik $0 \%$.

2. Self-regulated learning dan kemandirian belajar berpengaruh positif terhadap prestasi belajar bahasa Arab siswi MA Mu'allimat Muhammadiyah Yogyakarta, baik secara mandiri maupun bersama-sama. Hasil ini memberikan petunjuk bahwa semakin tinggi self-regulated learning dan kemandirian belajar siswi maka semakin tinggi pula hasil prestasi belajar bahasa Arab siswi. Self-regulated kearning

3. memberikan kontribusi sebesar 28,2\%, sedangkan kontribusi kemandirian belajar sebesar 18,5\% dan kontribusi secara bersama-sama sebesar $(11,9 \%)$, sedangkan sisanya $88,1 \%$ dipengaruhi oleh variabel 
lain di luar penelitian seperti motivasi, kediplinan, lingkungan belajar, metode dan gaya mengajar guru, sarana-prasarana dam fasilitas pembelajaran yang turut mendukung. Dari kesemua factor yang mendukung keberhasilan meraih prestasi belajar juga dibutuhkan strategi dan upaya yang gigih dalam belajar.

4. Variabel yang paling berpengaruh besar secara positif dan signifikan terhadap hasil prestasi belajar bahasa Arab di kelas X Multilingual MA Mu'allimat Muhammadiyah Yogyakarta adalah variabel self-regulated learning sebesar 28,2\% dibanding variabel kemandirian belajar sebesar 18,5\%. Meski prosentase pengaruh self-regulated learning dan kemandirian belajar terhadap prestasi belajar bahasa Arab tidak terlalu besar namun memiliki pengaruh yang positif terhadap hasil belajar siswi. Hal tersebut juga dipengaruhi oleh variabel lain yang turut mendukung seperti motivasi, kedisiplinan, lingkungan belajar, gaya mengajar guru, sarana-prasarana dan fasilitas pembelajaran. Siswi kelas X MA Mu'allimat Muhammadiyah tergolong siswi pilihan karena diwajibkan menetap di asrama dan persyaratan pada awal masuk madrasah siswi diharuskan memiliki nilai rata-rata 8. 


\section{DAFTAR PUSTAKA}

Arikunto, Suharsimi. Prosedur Penelitian Suatu Pendekatan Praktik. Jakarta: PT.Rineka Cipta. 2010.

Ali Mohammad dan Mohammad Asrori, Psikologi Remaja Perkembangan Peserta Didik, Jakarta: PT. Bumi Aksara, 2006.

Asyrofi, Syamsudin. Analisis Teks Book. Yogyakarta: UIN Sunan Kalijaga Press. 1988.

Diknas. Kamus Besar Bahasa Indonesia. Jakarta: Balai Pustaka. 2005.

Fasikhah, Siti Suminarti dan Siti Fatimah. Self-Regulated Learning dalam Meningkatkan Prestasi Akademik pada Mahasiswa, dalam Jurnal Ilmiah Psikologi Terapan. pdf. diunduh pada 15 Nov 2015.

Maemun, Muhammad. Pengaruh Kemandirian Belajar dan Fasilitas Belajar di Rumah Dengan Prestasi Belajar Biologi Siswa Kelas X MAN Wonokromo. Yogyakarta. 2007.

M. Dalyono, Psikologi Pendidikan. Jakarta: Rineka Cipta. 2009.

Nugroho. Self-Regulated Learning Anak Berbakat. Jakarta: Direktorat Pendidikan Luar Biasa, 2004.

Schunk, D.H. dan B.J. Zimmerman. Self-regulated Learning: From Teaching to Self-Reflective Practice. New York: The Guilford Press. 1998.

Suryabrata, Sumadi. Psikologi Pendidikan. Jakarta: PT. Raja Grafindo. 2006.

Suyono dan Hariyanto, Belajar dan Pembelajaran: Teori dan Konsep Dasar. Bandung: PT. Remaja Rosda Karya Offset - Bandung. 2011.

Syah, Muhibbin. Psikologi Pendidikan dengan Pendidikan Baru. Bandung: PT. Remaja Rosda Karya. 2008.

S. Margono, Metode Penelitian Pendidikan, Jakarta: PT.Rineka Cipta, 2004. Umar dan La Sulo. Pengantar Pendidikan. Jakarta: PT. Rineka Cipta. 2005.

Zimmerman, B.J. A Social Cognitive View of Self -Regulated Academic Learning. Journal of Educational Psychology. 1989. 